\title{
1 Indirect nitrous oxide emission factors for agricultural field drains and 2 headwater streams
}

3

4 Zanist Q. Hama-Aziz ${ }^{1}$, Kevin M. Hiscock ${ }^{1}$, Richard J. Cooper ${ }^{1 *}$

$5 \quad{ }^{1}$ School of Environmental Sciences, University of East Anglia, Norwich Research Park, Norwich NR4

6 7TJ, UK

8 ABSTRACT

9 Agriculture is a major source of nitrous oxide $\left(\mathrm{N}_{2} \mathrm{O}\right)$ emissions, a potent greenhouse gas. Whilst direct $10 \quad \mathrm{~N}_{2} \mathrm{O}$ emissions from soils have been widely investigated, indirect $\mathrm{N}_{2} \mathrm{O}$ emissions from nitrogen $(\mathrm{N})$ 11 enriched surface water and groundwater bodies are poorly understood. In this contribution, indirect $12 \mathrm{~N}_{2} \mathrm{O}$ emissions from subsurface agricultural field drains and headwater streams were monitored over a two-year period (2013-2015) in an intensive arable catchment in eastern England. Indirect $\mathrm{N}_{2} \mathrm{O}$ emission factors for groundwater $\left(\mathrm{EF}_{5 \mathrm{~g}}\right)$ and surface runoff $\left(\mathrm{EF}_{5 \mathrm{r}}\right)$ were calculated for both field drain and stream water samples, respectively, using two approaches: the $\mathrm{N}_{2} \mathrm{O}-\mathrm{N} / \mathrm{NO}_{3}^{-}-\mathrm{N}$ ratio and the IPCC (2006) methodology. Mean $\mathrm{EF}_{5 \mathrm{~g}}$ values derived from the $\mathrm{N}_{2} \mathrm{O}-\mathrm{N} / \mathrm{NO}_{3}^{-}-\mathrm{N}$ ratio were 0.0012 for field drains and 0.0003 for stream water. Using the IPCC (2006) methodology, the mean $\mathrm{EF}_{5 \mathrm{~g}}$ values were 0.0011 for field drains and 0.0001 for stream water. Thus, EF values derived from both methods were below the current IPCC (2006) default value of 0.0025 and a downward revision to 0.0012 for $\mathrm{EF}_{5 \mathrm{~g}}$ and 0.0002 for $\mathrm{EF}_{5 \mathrm{r}}$ is recommended. Such revision would halve current estimates of $\mathrm{N}_{2} \mathrm{O}$ emissions associated with nitrogen leaching and runoff from agriculture for both the UK and globally.

Keywords: nitrous oxide; emission factor; IPCC; nitrate; greenhouse gas; river; field drain 
Nitrous oxide $\left(\mathrm{N}_{2} \mathrm{O}\right)$ is a potent greenhouse gas with a present atmospheric concentration of $326.7 \mathrm{ppb}$

$27{ }^{1}$. Not only does $\mathrm{N}_{2} \mathrm{O}$ have a global warming potential 300 times that of $\mathrm{CO}_{2}{ }^{2}$, it also participates in photochemical reactions in the stratosphere which lead to the destruction of ozone $\left(\mathrm{O}_{3}\right)^{3}$. The concentration of $\mathrm{N}_{2} \mathrm{O}$ in the atmosphere is currently increasing at an annual rate of $\sim 0.26 \%{ }^{4}$ and agriculture is considered to be the largest source $(\sim 60 \%)$ of anthropogenic $\mathrm{N}_{2} \mathrm{O}$ emissions ${ }^{5}$. The Intergovernmental Panel on Climate Change (IPCC) ${ }^{6}$ has developed protocols for quantifying and generating national inventories of $\mathrm{N}_{2} \mathrm{O}$ emissions from industry, agriculture and natural ecosystems, with total $\mathrm{N}_{2} \mathrm{O}$ emissions from agriculture being categorised into direct and indirect sources. Whilst direct $\mathrm{N}_{2} \mathrm{O}$ emissions as a result of nitrogen $(\mathrm{N})$ application to soils have been widely investigated, indirect emissions produced in surface waters and groundwaters from agricultural $\mathrm{N}$ leaching and runoff have, to date, been less well studied ${ }^{7}$.

Indirect $\mathrm{N}_{2} \mathrm{O}$ emission factors $\left(\mathrm{EF}_{5}\right)$ are a way of representing $\mathrm{N}_{2} \mathrm{O}$ emissions from a water body as a fraction of the original $\mathrm{N}$ flux into the system ${ }^{8}$. The IPCC $^{6}$ defined $\mathrm{N}_{2} \mathrm{O}$ emission factors for $\mathrm{N}$ leaching and runoff from managed soils as follows (Equation 1):

$\mathrm{EF}_{5}=\frac{\mathrm{N}_{2} \mathrm{O}_{(\mathrm{L})}-\mathrm{N}}{\left(\text { Total } \mathrm{N} \text { input } \times \mathrm{Frac}_{\mathrm{LE} Æ C K}\right)}$

where, $E F_{5}$ is the $\mathrm{N}_{2} \mathrm{O}$ emission factor $\left(\mathrm{kg} \mathrm{N} \mathrm{N}_{2} \mathrm{O}-\mathrm{N} / \mathrm{kg} \mathrm{N}\right.$ ) with a default value of 0.0075 (range $=$ 0.0005-0.025); $N_{2} O_{(L)}-N$ is the emission of $\mathrm{N}_{2} \mathrm{O}$ produced by the leaching and runoff of $\mathrm{N}$ additions to managed soils $\left(\mathrm{kg} \mathrm{N}_{2} \mathrm{O}-\mathrm{N} \mathrm{a}^{-1}\right)$; Total $\mathrm{N}$ input is the total annual amount of $\mathrm{N}$ added to the system, including synthetic fertilisers and animal manure, that is lost through leaching and runoff $\left(\mathrm{kg} \mathrm{N} \mathrm{a}^{-1}\right)$; and Frac $_{L E A C H}$ is the fraction of all $\mathrm{N}$ added to, or mineralised within, managed soils that is lost through leaching and runoff $\left(\mathrm{kg} \mathrm{N} / \mathrm{kg}\right.$ of $\mathrm{N}$ additions $\left.\mathrm{a}^{-1}\right)$, with a default value of $30 \%$ (range $=10_{-}$ $80 \%)$ Equation 1, or by measuring indirect $\mathrm{N}_{2} \mathrm{O}$ emissions from dissolved $\mathrm{N}_{2} \mathrm{O}$ concentrations and then 
using this equation to calculate $\mathrm{EF}_{5}$. The IPCC ${ }^{6}$ revised the default emission factor for indirect $\mathrm{N}_{2} \mathrm{O}$

51 emissions $\left(\mathrm{EF}_{5}\right)$ from $0.025 \mathrm{~kg} \mathrm{~N} \mathrm{~N}_{2} \mathrm{O}-\mathrm{N} / \mathrm{kg} \mathrm{N}$ in 1997 to $0.0075 \mathrm{~kg} \mathrm{~N} \mathrm{~N}_{2} \mathrm{O}-\mathrm{N} / \mathrm{kg} \mathrm{N}$ in 2006. The EF $\mathrm{Fas}$ further divided into three components according to the site of $\mathrm{N}_{2} \mathrm{O}$ production: $\mathrm{EF}_{5 \mathrm{~g}}$ for groundwater and surface drainage (0.0025); $\mathrm{EF}_{5 \mathrm{r}}$ for rivers $(0.0025)$; and $\mathrm{EF}_{5 \mathrm{e}}$ for estuaries $(0.0025)$, thus giving an overall $\mathrm{EF}_{5}$ of $0.0075 . \mathrm{EF}_{5}$ has a wide range of uncertainty (0.0005-0.025) as a result of natural variability and a lack of data to support designation. However, as many studies are often lacking the detailed mass balance information needed to determine $\mathrm{EF}_{5}$ and evaluate national $\mathrm{N}_{2} \mathrm{O}$ inventories by

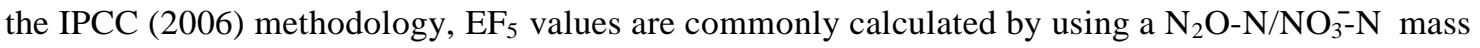
ratio derived using the concentration data of $\mathrm{N}_{2} \mathrm{O}$ and nitrate $\left(\mathrm{NO}_{3}\right)$ collected from the water body. Therefore, most studies on emission factors from leaching and runoff calculate $\mathrm{EF}_{5}$ by the following $60 \operatorname{method}^{7,9,10-17}$ (Equation 2):

$\mathrm{EF}_{5}=\frac{\mathrm{N}_{2} \mathrm{O}-\mathrm{N}}{\mathrm{NO}_{3}-\mathrm{N}}$ where $\mathrm{N}_{2} \mathrm{O}-\mathrm{N}$ and $\mathrm{NO}_{3}-\mathrm{N}$ are concentrations measured in groundwater, rivers or estuaries. The objectives of this study are as follows:

64 i. To calculate indirect $\mathrm{N}_{2} \mathrm{O}$ emission factors for subsurface agricultural field drains $\left(\mathrm{EF}_{5 \mathrm{~g}}\right)$ and headwater streams $\left(\mathrm{EF}_{5 \mathrm{r}}\right)$ in an intensive arable catchment;

ii. To assess the extent of temporal variability in indirect $\mathrm{N}_{2} \mathrm{O}$ emission factors; default $\mathrm{EF}_{5 \mathrm{~g}}$ and $\mathrm{EF}_{5 \mathrm{r}}$ values of 0.0025 and assess whether these general emission factors are appropriate for predicting $\mathrm{N}_{2} \mathrm{O}$ emissions in a temperate, lowland arable environment. factors used in future IPCC assessment reports. 


\section{2. Materials and Methods}

\section{$74 \quad 2.1$ Study location}

75 The study area is in the Blackwater sub-catchment of the River Wensum, Norfolk, UK (Figures S176 S5). The Blackwater sub-catchment is intensively monitored as part of the Wensum Demonstration 77 Test Catchment (DTC) project which aims to evaluate the extent to which on-farm mitigation measures can cost-effectively reduce the impact of diffuse agricultural pollution on aquatic ecology whilst still maintaining food production capacity ${ }^{18}$. The area is under intensive arable cultivation with spring and winter barley, winter wheat, winter oilseed rape, spring beans and sugar beet grown in a seven-year rotation. The average annual rainfall total is $674 \mathrm{~mm}$ and the mean annual temperature is $10.1^{\circ} \mathrm{C}^{19}$. The western section of the Blackwater sub-catchment, hereafter termed "mini-catchment $\mathrm{A}$ " $\left(5.4 \mathrm{~km}^{2}\right)$, is extensively under-drained by a dense network of agricultural tile drainage installed at a depth of 100-160 cm below the ground surface. Discharge from drains can be as high as $10 \mathrm{~L} \mathrm{~s}^{-1}$, but varies greatly depending upon season, depth, catchment area and antecedent moisture conditions, with most drains drying up completely during the summer months. The geology of the catchment is comprised of Middle Pleistocene glacial deposits (0.5-20 m depth) overlying Cretaceous White Chalk (>20 m depth), with surface soils varying from sandy loam to sandy clay loam and clay loam.

\subsection{Sample collection}

Over a two-year period (April 2013 to April 2015), a total of 929 water samples were collected from

9113 field drains ( $n=621$ ) and four stream locations (sites A, B, E and $\mathrm{M} ; n=308$ ) for $\mathrm{N}_{2} \mathrm{O}$ and nutrient analysis (Figure S1). Samples were collected at weekly intervals, with the exception of AprilSeptember 2014 when field drains were sampled fortnightly and stream waters monthly. For dissolved $\mathrm{N}_{2} \mathrm{O}$ concentrations, samples were collected at field drain outlet pipes and from stream waters using $20 \mathrm{~mL}$ glass syringes (SAMCO) with a three-way stopcock attached to each syringe by a Luer-Lock fitting. Syringes were flushed three times with water from the sampling point and any air bubbles contained in the syringes were expelled before the final sample was taken. A single sample was taken 
$4^{\circ} \mathrm{C}$ within $3 \mathrm{~h}$ and analysed for $\mathrm{N}_{2} \mathrm{O}$ within $72 \mathrm{~h}$ of collection. For the nutrient analysis, water samples were collected in $1 \mathrm{~L}$ plastic bottles and were also analysed within $72 \mathrm{~h}$ of collection. Field drain flow was estimated in triplicate on each sampling occasion. Stream stage was measured at each of the four stream sampling sites using a pressure transducer and converted into flow using a stagedischarge rating curve. Maps of the field drain network were provided by the local farmer and the drainage area of each drain was estimated by polygon digitising using GIS (Figure S1). Wind speed data required for calculating $\mathrm{N}_{2} \mathrm{O}$ emissions from streams were obtained from a weather station installed in mini-catchment A.

\subsection{Sample analysis}

Dissolved $\mathrm{N}_{2} \mathrm{O}$ was analysed by gas chromatography with an electron capture detector (GC-ECD). Accuracy of $\mathrm{N}_{2} \mathrm{O}$ measurements was within $\pm 3 \%$ with a detection limit of $\sim 0.0008 \mu \mathrm{g} \mathrm{N} \mathrm{L}^{-1}$. Nitrate was determined by ion chromatography using a Dionex ISC 2000 with an accuracy of $0.19 \mathrm{mg} \mathrm{N} \mathrm{L}^{-1}$. Ammonium $\left(\mathrm{NH}_{4}\right)$ and nitrite $\left(\mathrm{NO}_{2}\right)$ were determined by a Continuous Flow Analyser - Skalar San++ with accuracies of $4.57 \mu \mathrm{g} \mathrm{N} \mathrm{L}^{-1}$ and $1.52 \mu \mathrm{g} \mathrm{N} \mathrm{L}^{-1}$, respectively. Total organic nitrogen was measured with a Skalar Formacs TOC/TN analyser with an accuracy of $0.08 \mathrm{mg} \mathrm{N} \mathrm{L}^{-1}$. Further details are provided in the supporting information.

\subsection{Emission factors and flux calculations}

Fluxes of $\mathrm{N}_{2} \mathrm{O}$ from field drains into the atmosphere were calculated based on the assumption that all of the dissolved $\mathrm{N}_{2} \mathrm{O}$ at concentrations above that of air saturation is subsequently lost to the atmosphere ${ }^{10,20-22}$. Thus, the air saturation concentration of $\mathrm{N}_{2} \mathrm{O}\left(0.36 \mu \mathrm{g} \mathrm{N} \mathrm{L}^{-1}\right)$, calculated using equilibrium equations ${ }^{23}$, was subtracted from the measured dissolved $\mathrm{N}_{2} \mathrm{O}$ concentration, then multiplied by flow rate and divided by drain area to obtain the $\mathrm{N}_{2} \mathrm{O}$ emission rates. Note, however, that because field drain samples were taken at the drain outlets, there may be losses of $\mathrm{N}_{2} \mathrm{O}$ from the drains prior to reaching the sampling point and thus estimates of $\mathrm{N}_{2} \mathrm{O}$ emissions could be underestimated in this study. $\mathrm{N}_{2} \mathrm{O}$ emission rates from stream water were calculated using the waterair gas exchange Equation ( 3$)^{7}$, as follows: 
$126 \quad \mathrm{~F}=\mathrm{kC}_{\mathrm{w}}-\frac{\mathrm{C}_{\mathrm{a}}}{\mathrm{kh}_{\mathrm{h}}}$

127 where $F$ is the flux (or emission) of gas $\left(\mathrm{mol} \mathrm{cm}^{-2} \mathrm{~h}^{-1}\right) ; k$ is the transfer velocity of $\mathrm{N}_{2} \mathrm{O}$ across the

128 water-air interface $\left(\mathrm{cm} \mathrm{h}^{-1}\right) ; C_{w}$ is the concentration of $\mathrm{N}_{2} \mathrm{O}$ in water $\left(\mathrm{mol} \mathrm{cm}^{-3}\right) ; C_{a}$ is the 129 concentration of $\mathrm{N}_{2} \mathrm{O}$ in air $\left(\mathrm{mol} \mathrm{cm}{ }^{-3}\right)$; and $k_{h}^{\prime}$ is the Henry's law constant for $\mathrm{N}_{2} \mathrm{O}$ which is 130 dimensionless and obtained from literature as $1.02^{24} . k$ was calculated using a combined gas transfer 131 velocity approach that incorporates both wind and water turbulence ${ }^{25}$. The water turbulence 132 component was calculated as follows (Equation 4):

$134 \quad \mathrm{k}_{\text {water }}=\mathbf{J} \frac{\overline{\mathrm{DV}}}{\mathrm{h}}$

$\mathrm{k}_{\text {wind }}=0.31 \mathrm{u}^{2}\left(\frac{\mathrm{Sc}}{660}\right)^{0.5}$ where $D$ is the $\mathrm{N}_{2} \mathrm{O}$ diffusion coefficient $\left(\mathrm{m}^{2} \mathrm{~s}^{-1}\right), V$ is the stream water velocity $\left(\mathrm{m} \mathrm{s}^{-1}\right)$ and $h$ is the stream water depth (m). The wind component was calculated as follows (Equation 5):

where $u$ is the wind speed $\left(\mathrm{cm} \mathrm{h}^{-1}\right)$ and $S c$ is the Schmidt number for $\mathrm{N}_{2} \mathrm{O}$. The wind and water components were then added together to form the combined gas transfer velocity, $k$.

For emission factors calculated by the IPCC (2006) methodology, FracLEACH was determined from the total load of dissolved organic and inorganic $\mathrm{N}$ in field drain and stream water, divided by the total $\mathrm{N}$ fertiliser input. For stream water, this was only calculated at site A (the outlet of mini-catchment $\mathrm{A}$ ) as this site had the most complete $\mathrm{N}$ fertiliser application data (2012-2014). 


\section{3. Results and Discussion}

\section{$146 \quad 3.1$ Concentration data}

147 Field drain and stream water $\mathrm{NO}_{3}$ and $\mathrm{N}_{2} \mathrm{O}$ concentrations for the period April 2013 to April 2015 are 148 presented in Figure 1 and summarised in Table 1. The mean $\mathrm{N}_{2} \mathrm{O}$ concentration recorded across all field drains $\left(4.49 \mu \mathrm{g} \mathrm{L}^{-1}\right)$ was significantly $(p<0.05)$ greater than that recorded for the streams $(1.43$ $\mu \mathrm{g} \mathrm{L}^{-1}$ ), which reflects the rapid degassing of $\mathrm{N}_{2} \mathrm{O}$ from field drain water upon contact with the atmosphere prior to reaching the stream. Conversely, the mean $\mathrm{NO}_{3}$ concentration recorded in field drains $\left(6.08 \mathrm{mg} \mathrm{L}^{-1}\right)$ was significantly lower $(p<0.05)$ than that recorded in stream water $\left(6.70 \mathrm{mg} \mathrm{\textrm {L } ^ { - }}\right.$

$153{ }^{1}$ ). In both field drains and streams, the mean $\mathrm{NO}_{3}\left(4.17\right.$ and $4.49 \mathrm{mg} \mathrm{L}^{-1}$, respectively) and $\mathrm{N}_{2} \mathrm{O}(3.20$ and $1.02 \mu \mathrm{g} \mathrm{L}^{-1}$, respectively) concentrations were significantly $(p<0.05)$ lower during the summer (JJA) than any other season. The highest mean $\mathrm{NO}_{3}$ concentrations in field drains $\left(6.47 \mathrm{mg} \mathrm{L}^{-1}\right)$ and streams $\left(8.30 \mathrm{mg} \mathrm{L}^{-1}\right)$ occurred during the winter, whereas the highest mean $\mathrm{N}_{2} \mathrm{O}$ concentrations in field drains occurred during the spring $\left(4.95 \mu \mathrm{g} \mathrm{L}^{-1}\right)$ and in streams during the autumn $\left(1.82 \mu \mathrm{g} \mathrm{L}^{-1}\right)$. 0.55 ) indicating that $\mathrm{NO}_{3}$ is an important driver of riverine $\mathrm{N}_{2} \mathrm{O}$ production in this catchment (Figure 1). However, in field drains the correlation between $\mathrm{N}_{2} \mathrm{O}$ and $\mathrm{NO}_{3}$ was much weaker $(r=0.19)$, implying a greater role from other biotic and abiotic factors in the production of $\mathrm{N}_{2} \mathrm{O}$ in soils. In contrast to previous studies ${ }^{26}$, there was no strong correlation between stream water $\mathrm{N}_{2} \mathrm{O}$ and either dissolved oxygen concentration $(r=0.19)$ or water temperature $(r=0.05)$,

\section{2 $\mathrm{N}_{2} \mathrm{O}-\mathrm{N} / \mathrm{NO}_{3}^{-}-\mathrm{N}$ ratio method}

The $\mathrm{EF}_{5 \mathrm{~g}}$ emission factor (ratio of $\mathrm{N}_{2} \mathrm{O}-\mathrm{N}$ to $\mathrm{NO}_{3}^{-}-\mathrm{N}$ ) in field drain samples varied between 0.00003 and 0.01063 , with a mean value of $0.00120 . \mathrm{The}^{\mathrm{EF}_{5 \mathrm{r}}}$ emission factor for stream water samples ranged from 0.00006 to 0.00282 , with a mean value of 0.00029 (Table 1). Thus, the $\mathrm{EF}_{5 \mathrm{~g}}$ emission factors for $90 \%$ of field drain samples collected in this study were lower than the IPCC default value of $0.0025^{6}$, whilst $\sim 15 \%$ of collected samples were one order of magnitude lower. Similarly, $100 \%$ of the stream 
samples $\left(\mathrm{EF}_{5 \mathrm{r}}\right)$ had emission factors lower than the IPCC default. These results indicate that the previously downward revised IPCC (2006) default value of 0.0025 may still be overestimating indirect $\mathrm{N}_{2} \mathrm{O}$ emissions in agricultural systems similar to that studied here.

As illustrated in Figure 1, the $\mathrm{N}_{2} \mathrm{O}-\mathrm{N} / \mathrm{NO}_{3}^{-}-\mathrm{N}$ ratios varied substantially across field drain and stream water samples. In this study, temporal variability in these ratios was monitored over the two-year sampling period (Figure 2). The mean $\mathrm{N}_{2} \mathrm{O}-\mathrm{N} / \mathrm{NO}_{3}^{-}-\mathrm{N}$ ratio of the stream water samples was significantly lower $(p<0.05)$ than that for the field drains throughout the entire study period, amounting to approximately one order of magnitude difference (Table 1). For both field drains and stream samples, EF ratios were observed to increase during the summer months (JJA) before returning to relatively stable levels in mid-autumn (October). The mean summer $\mathrm{EF}_{5 \mathrm{r}}$ for the stream sites (0.00039) was significantly $(p<0.05)$ higher than that recorded in winter or spring, although it was the same as that recorded during the autumn (Table 1). In the field drains, the mean summer $\mathrm{EF}_{5 \mathrm{~g}}$ $(0.00135)$ was higher than any other season, although wide variability meant this difference was not significant $(p>0.05)$. This trend was repeated in both sampling years and appears to be due to the substantial decrease in $\mathrm{NO}_{3}$ concentrations during the summer as a result of a decline in water flow and a decline in potentially leachable $\mathrm{NO}_{3}$ due to nutrient uptake by crops during this period. This summer period of high EF ratios represents $\sim 10 \%$ of collected samples shown in Figure 2. It is clear from the data presented here that EF values varied over time and it may be more appropriate to have different EF values for different seasons rather than one EF value throughout the year, as is suggested by the IPCC ${ }^{6}$.

\subsection{IPCC 2006 method}

In this study, it was possible to estimate $\mathrm{EF}_{5}$ emission factors using the $\mathrm{IPCC}^{6}$ methodology. Unlike the $\mathrm{N}_{2} \mathrm{O}-\mathrm{N} / \mathrm{NO}_{3}-\mathrm{N}$ ratio method, this approach requires more detailed flow, nutrient input and spatial information which were available here for all field drains and for stream site A (the outlet of minicatchment A) (Table 2 and Figure 3). The total field drainage area in mini-catchment A was estimated to be 21.14 ha, whilst the stream surface water area was estimated to be 0.33 ha. Measured field drain flow rates during the study period ranged from 0.001 to $2.35 \mathrm{~L} \mathrm{~s}^{-1}$ with an average for all drains of 
$0.14 \mathrm{~L} \mathrm{~s}^{-1}$. Field drain flow rate was positively correlated $(r=0.53)$ with field drainage area. Measured stream flows at site A ranged from 2 to $271 \mathrm{~L} \mathrm{~s}^{-1}$, with a mean flow rate of $25.4 \mathrm{~L} \mathrm{~s}^{-1}$. Using these flow data, the calculated mean $\mathrm{N}_{2} \mathrm{O}$ emission rate across all field drains during the study period was $0.05 \mathrm{~kg} \mathrm{~N} \mathrm{ha}^{-1} \mathrm{a}^{-1}$. In contrast, the mean $\mathrm{N}_{2} \mathrm{O}$ emission rate for stream water in mini-catchment $\mathrm{A}$ was significantly $(p<0.05)$ higher, with a calculated rate of $5.75 \mathrm{~kg} \mathrm{~N} \mathrm{ha}^{-1} \mathrm{a}^{-1}$.

Total N input for mini-catchment A was calculated for the 2012-2013 and 2013-2014 farming years using available farm business data (Figure 3). The total $\mathrm{N}$ fertiliser applied across the whole of minicatchment A was 67,985 $\mathrm{kg} \mathrm{N} \mathrm{a}^{-1}$ in 2012-2013 and 61,106 $\mathrm{kg} \mathrm{N} \mathrm{a}^{-1}$ in 2013-2014, thus giving an annual mean fertiliser application of $64,545 \mathrm{~kg} \mathrm{~N}$. For the field drain area, the total applied $\mathrm{N}$ fertiliser was 2,659 $\mathrm{kg} \mathrm{N} \mathrm{a}^{-1}$ for 2012-2013 and 3,080 $\mathrm{kg} \mathrm{N} \mathrm{a}^{-1}$ for 2013-2014, giving a mean fertiliser application rate of $2,870 \mathrm{~kg} \mathrm{~N} \mathrm{a}^{-1}$ (Table2).

For stream site A, a mean of $15,885 \mathrm{~kg} \mathrm{~N} \mathrm{a}^{-1}$ were lost during the two years through leaching from the total applied $\mathrm{N}$ of $64,545 \mathrm{~kg} \mathrm{~N} \mathrm{a}^{-1}$, giving a mean Frac $\mathrm{LEACH}_{\mathrm{L}}$ of $25 \%$. For the field drains, Frac $_{\mathrm{LEACH}}$ was calculated separately for each drain from the $\mathrm{N}$ leached divided by the total $\mathrm{N}$ applied over a given field drain area, giving a mean estimated Frac $\mathrm{LEACH}_{\mathrm{L}}$ value for all drains of $34 \%$. This mean

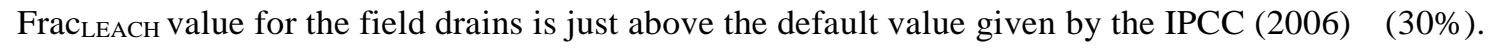
However, a wide uncertainty range $(10-80 \%)$ is given by the IPCC $^{6}$ and a similarly wide range of

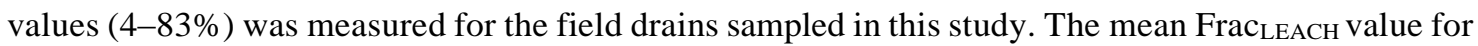
the stream (25\%) was lower than for the field drains, albeit not significantly ( $p>0.05$ ), which is potentially explained by dilution from groundwater with a lower $\mathrm{NO}_{3}$ concentration (note groundwater $\mathrm{NO}_{3}$ was not analysed in the study).

Overall, an $\mathrm{EF}_{5 \mathrm{~g}}$ of 0.0011 was calculated for the field drains using the IPCC (2006) methodology, whilst an $\mathrm{EF}_{5 \mathrm{r}}$ of 0.0001 was calculated for stream water at site A (Table 2). Both these estimates are substantially below the current IPCC default EF value of 0.0025 . 


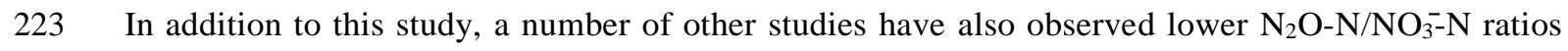
$224\left(\mathrm{EF}_{5 \mathrm{~g}}\right)$ in both groundwater and river water than the IPCC (2006) default value (Table S3). An $\mathrm{EF}_{5 \mathrm{~g}}$ 225 value of 0.0019 was calculated for chalk groundwater in eastern England ${ }^{13}$, whilst a value of 0.0008 226 was calculated for field drain water on arable land in the upper Neckar region, Southern Germany ${ }^{10}$. 227 Conversely, only a few studies have calculated $\mathrm{EF}_{5 \mathrm{~g}}$ values higher than the current IPCC (2006) 228 default value. A value of 0.0030 (range 0.00008-0.036) was derived for water samples collected from 229 field drain outfalls in an intensively managed grazed pasture in the Ythan catchment, Aberdeenshire $230{ }^{11}$, whilst a value of $0.0028(0.0012-0.0069)$ was calculated for $\mathrm{EF}_{5 \mathrm{r}}$ in a study of the eutrophic San 231 Joaquin River, California ${ }^{16}$.

232 According to current IPCC ${ }^{6}$ protocol, stream water $\left(\mathrm{EF}_{5 \mathrm{r}}\right)$ and groundwater $\left(\mathrm{EF}_{5 \mathrm{~g}}\right)$ are assigned the 233 same emission factor of 0.0025 . However, it is clear from the data presented here that stream water had significantly $(p<0.05)$ lower EF values $($ mean $=0.0002)$ than field drains $($ mean $=0.0012)$. These low stream water $\mathrm{EF}_{5 \mathrm{r}}$ values reflect the low dissolved $\mathrm{N}_{2} \mathrm{O}$ concentrations recorded in streams and are likely a consequence of the rapid degassing of $\mathrm{N}_{2} \mathrm{O}$ from field drains upon contact with the atmosphere prior to reaching the stream. Different $\mathrm{EF}_{5}$ emission factors for different water compartments within a single catchment have been reported previously ${ }^{7}$, and this highlights the need to distinguish $\mathrm{EF}_{5}$ among different hydrological environments.

Critically examining the default Frac $_{\mathrm{LEACH}}$ value, a review of six case studies in the Midwestern

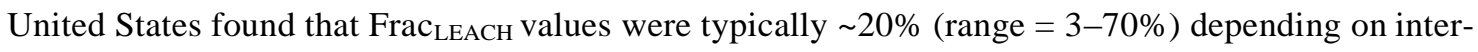
annual variability in rainfall ${ }^{27}$. One of the reasons that this comparatively low Frac $\mathrm{LEACH}_{\text {value }}$ was obtained in all six of these case studies was that organic $\mathrm{N}$ was not considered as a component, even though it may constitute a significant fraction of the total leached $\mathrm{N}^{28}$. Consequently, this could lead to a substantial underestimate of the true amount of $\mathrm{N}$ leaching. The calculated Frac LEACH values $_{\text {in }}$ this study (which included both organic and inorganic $\mathrm{N}$ ) of $34 \%$ and $25 \%$ for field drains and stream water, respectively, are similar to the modelling results for the UK as a whole in which Frac $\mathrm{LEACH}_{\mathrm{H}}$ values of $16-24 \%$ were estimated for the Norfolk area ${ }^{29}$. 
250

251

252

The results from this study show that both the $\mathrm{EF}_{5 \mathrm{~g}}$ and $\mathrm{EF}_{5 \mathrm{r}}$ values were lower using the IPCC (2006) ${ }^{6}$ methodology than the $\mathrm{N}_{2} \mathrm{O}-\mathrm{N} / \mathrm{NO}_{3}^{-}-\mathrm{N}$ ratio approach (Table 2). The lower $\mathrm{EF}_{5 \mathrm{~g}}$ value calculated using the IPCC methodology was expected based on previous research ${ }^{30}$ which has shown that denitrification in near-surface groundwater can result in some of the leached $\mathrm{NO}_{3}$ and $\mathrm{N}_{2} \mathrm{O}$ being denitrified before groundwater is discharged into the stream.

Calculation of $\mathrm{EF}_{5 \mathrm{~g}}$ and $\mathrm{EF}_{5 \mathrm{r}}$ values using the two different approaches clearly does not necessarily ensure the same result. Most studies calculate $\mathrm{EF}_{5 \mathrm{~g}}$ using the $\mathrm{N}_{2} \mathrm{O}-\mathrm{N} / \mathrm{NO}_{3}^{-}-\mathrm{N}$ ratio since detailed mass balance information is often lacking and few studies calculate $\mathrm{EF}_{5 \mathrm{~g}}$ using the IPCC (2006) approach even if they have detailed mass balance information available for a catchment. However, Outram and Hiscock (2012) calculated the $\mathrm{EF}_{5 \mathrm{~g}}$ for different water bodies using both approaches and found that values of $\mathrm{EF}_{5 \mathrm{~g}}$ calculated using the IPCC approach were very different from those calculated using the $\mathrm{N}_{2} \mathrm{O}-\mathrm{N} / \mathrm{NO}_{3}-\mathrm{N}$ ratio ${ }^{7}$. The $\mathrm{EF}_{5 \mathrm{~g}}$ calculated for drainage channels using the IPCC (2006) approach was found to be an order of magnitude higher than that obtained when using the $\mathrm{N}_{2} \mathrm{O}-\mathrm{N} / \mathrm{NO}_{3}^{-}-\mathrm{N}$ ratio, with values of 0.0530 and 0.0061 , respectively ${ }^{7}$. Similarly, the $\mathrm{EF}_{5 \mathrm{r}}$ calculated for the River Thurne using the IPCC (2006) approach was nine times higher than that calculated using the $\mathrm{N}_{2} \mathrm{O}-\mathrm{N} / \mathrm{NO}_{3}^{-}-\mathrm{N}$ ratio, with values of 0.0090 and 0.0011 , respectively ${ }^{7}$. Therefore, to achieve an accurate result and avoid miscalculation from using different approaches, the IPCC (2006) may need to propose one comprehensive and consistent approach.

According to this study, regardless of the method used for calculation of $\mathrm{EF}_{5 \mathrm{~g}}$ and $\mathrm{EF}_{5 \mathrm{r}}$, the default value set by IPCC ${ }^{6}$ of 0.0025 appears to overestimate indirect $\mathrm{N}_{2} \mathrm{O}$ emissions (Table 2). The default value is one order of magnitude higher than the $\mathrm{EF}_{5 \mathrm{r}}$ for stream water calculated by either method,

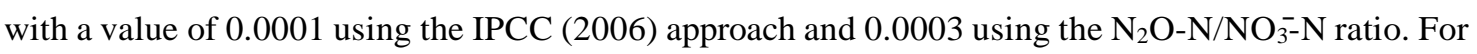
the field drains, the default $\mathrm{EF}_{5 \mathrm{~g}}$ value is more than double that calculated using the IPCC (2006) approach (0.0011) and the $\mathrm{N}_{2} \mathrm{O}-\mathrm{N} / \mathrm{NO}_{3}^{-}-\mathrm{N}$ ratio (0.0012). Furthermore, the $\mathrm{EF}_{5}$ values calculated using both the IPCC (2006) methodology and the $\mathrm{N}_{2} \mathrm{O}-\mathrm{N} / \mathrm{NO}_{3}-\mathrm{N}$ ratio revealed that emissions factors are not uniform for different water bodies. Hence, within a single catchment different water bodies can 
yield different amounts of $\mathrm{N}_{2} \mathrm{O}$ with unique emission factor values. Ideally, different water bodies need to be separated when emission factors are calculated, unlike the current IPCC (2006) approach which uses one $\mathrm{EF}$ value for all water bodies. If the $\mathrm{EF}_{5}$ emission factor was to be revised by the IPCC, regardless of soil type, crop type and land use practices, then a value of 0.0012 (about half of the current value) for $\mathrm{EF}_{5 \mathrm{~g}}$ and a value of 0.0002 (one order of magnitude lower than the current value) for $\mathrm{EF}_{5 \mathrm{r}}$ may be more reasonable estimates for the type of system studied here.

\subsection{Implications of the measured EF values}

The results of this study suggest that the indirect emissions component of the UK agricultural $\mathrm{N}_{2} \mathrm{O}$ budget may be overestimated using the current default emission factor $\left(\mathrm{EF}_{5}\right)$. Revision of this emission factor in line with the findings presented here would result in a large reduction in the estimated $\mathrm{N}_{2} \mathrm{O}$ emissions in both the UK and globally (Table 3). For the UK, the indirect $\mathrm{N}_{2} \mathrm{O}$ emissions arising from $\mathrm{N}$ leaching and runoff from agroecosystems total $\sim 14.3 \mathrm{Gg} \mathrm{N} \mathrm{a}^{-1}$, based on the 1997 guideline default $\mathrm{EF}_{5}$ value of $0.025^{31}$. Using the revised $\mathrm{IPCC}^{6} \mathrm{EF}_{5}$ value of 0.0075 , these indirect emissions were reduced significantly to $6.71 \mathrm{Gg} \mathrm{N}_{2} \mathrm{O}-\mathrm{N} \mathrm{a}^{-132}$. If the calculated value for $\mathrm{EF}_{5}$ of 0.0039 (the sum of all $\mathrm{EF}_{5 \mathrm{~g}}, \mathrm{EF}_{5 \mathrm{r}}$ and $\mathrm{EF}_{5 \mathrm{e}}$ ) in this study is applied, these emissions would be further reduced to $3.49 \mathrm{Gg} \mathrm{N}_{2} \mathrm{O}-\mathrm{N} \mathrm{a}^{-1}$ (Table 3).

Similarly, global estimates of indirect $\mathrm{N}_{2} \mathrm{O}$ emissions from leaching and runoff would be reduced by using the emission factors calculated here. Initially, these emissions were estimated to be $1.90 \mathrm{Tg}$ $\mathrm{N}_{2} \mathrm{O}-\mathrm{N} \mathrm{a}^{-1}$ based on the default value for $\mathrm{EF}_{5}$ of 0.025 reported by the IPCC in 1997. However, with a revised default value of 0.0075 , these estimates were substantially reduced to $0.60 \mathrm{Tg} \mathrm{N}_{2} \mathrm{O}-\mathrm{N} \mathrm{a}^{-1}$ in $2006^{32}$. Should the suggested emission factor from this study (0.0039) be applied to global indirect $\mathrm{N}_{2} \mathrm{O}$ emissions, the estimates would be further reduced to $0.31 \mathrm{Tg} \mathrm{N}_{2} \mathrm{O}-\mathrm{N} \mathrm{a}^{-1}$. This emphasises that despite the revision of emission factors in 2006, the current IPCC inventory may still overestimate actual $\mathrm{N}_{2} \mathrm{O}$ emissions. If the emission factors calculated in this study were to be applied, further significant reductions in indirect $\mathrm{N}_{2} \mathrm{O}$ emissions similar to the level of reductions achieved in the 2006 revision, would again be observed. Several studies investigating emission factors and indirect $\mathrm{N}_{2} \mathrm{O}$ emissions from leaching and runoff have been carried out since 2006 which suggest lowering of the 
304 new findings is recommended.

\section{Supporting Information}

306 The supporting information contains additional details on the analytical methods, a location map and

307 photographs of the study site, summary tables of field drain and stream water data, and a review table 308 of previously published $\mathrm{N}_{2} \mathrm{O}$ emission factor values.

309 Author Information

310 *Corresponding Author: Richard J. Cooper; Richard.J.Cooper@uea.ac.uk; +44(0)1603592922;

311 School of Environmental Sciences, University of East Anglia, Norwich Research Park, Norwich NR4 $3127 \mathrm{TJ}, \mathrm{UK}$

\section{Acknowledgements}

315 This research was funded by the Defra Agricultural Greenhouse Gas Platform (project AC0116) and

316 Iraqi Kurdistan Regional Government. The authors would like to thank: Gilla Sünnenberg for GIS 317 mapping; Jenny Stevenson, Christopher Adams, Faye Outram, Simon Ellis, Nick Garrard, Steve 318 Warnes and Steve Dugdale for fieldwork support; Ayan Fleischmann and Lucas Favero for mapping 319 and calculating field drain areas; and Liz Rix, Alina Mihailova, Kim Goodey, Tony Hinchliffe and 320 Andy Hind for laboratory analytical support. The authors would like to thank the Salle Park Estate for 321 their cooperation in providing access to the field sites.

\section{References}

323 (1) European Environment Agency; Atmospheric concentration of carbon dioxide, methane and 324 nitrous oxide. http://www.eea.europa.eu/data-and-maps/daviz/atmospheric-concentration-of-carbon325 dioxide-2\#tab-chart_4.

326 (2) Omonode, R. A.; Smith, D. R.; Gál, A.; Vyn, T. J. Soil nitrous oxide emissions in corn following 327 three decades of tillage and rotation treatments. Soil Science Society of America Journal 2011, 75, (1), $328 \quad 152-163$. 
(3) Jacinthe, P.-A.; Dick, W. A. Soil management and nitrous oxide emissions from cultivated fields

330 in southern Ohio. Soil and Tillage Research 1997, 41, (3-4), 221-235.

331 (4) Forster, P.; Ramaswamy, V.; Artaxo, P.; Berntsen, T.; Betts, R.; Fahey, D. W.; Haywood, J.; Lean,

332 J.; Lowe, D. C.; Myhre, G. Changes in atmospheric constituents and in radiative forcing. Climate

333 Change 2007, 20, (7), 129-234.

334 (5) Smith, P.; Martino, D.; Cai, Z.; Gwary, D.; Janzen, H.; Kumar, P.; McCarl, B.; Ogle, S.; O’Mara,

335 F.; Rice, C.; Scholes, B.; Sirotenko, O. Agriculture. Climate Change 2007: mitigation; Cambridge

336 University Press, Cambridge, UK, and New York, 2007.

337 (6) De Klein, C.; et al. $\mathrm{N}_{2} \mathrm{O}$ emissions from managed soils, and $\mathrm{CO}_{2}$ emissions from lime and urea

338 application. In IPCC guidlines for national greenhouse gas inventories; Eggelston, S., Buendia, L.,

339 Miwa, K., Ngara, T., Tanabe, K., Eds.; Intergovernmental Panel for Climate Change (IPCC), UN

340 and WMO 2006; p 54.

341 (7) Outram, F. N.; Hiscock, K. M. Indirect nitrous oxide emissions from surface water bodies in a

342 lowland arable catchment: a significant contribution to agricultural greenhouse gas budgets?

343 Environmental Science \& Technology 2012, 46, (15), 8156-8163.

344 (8) Well, R.; Weymann, D.; Flessa, H. Recent research progress on the significance of aquatic

345 systems for indirect agricultural $\mathrm{N}_{2} \mathrm{O}$ emissions. Environmental Sciences 2005, 2, (2-3), 143-151.

346 (9) Reay, D.; Edwards, A.; Smith, K. Determinants of nitrous oxide emission from agricultural

347 drainage waters. Water, Air \& Soil Pollution: Focus 2004, 4, (6), 107-115.

348 (10) Hack, J.; Kaupenjohann, M. $\mathrm{N}_{2} \mathrm{O}$ discharge with drain water from agricultural soils of the upper

349 Neckar region in Southern Germany. In Non- $\mathrm{CO}_{2}$ greenhouse gases: scientific understanding, control

350 options and policy aspects. Proceedings of the Third International Symposium, , Van Ham, J.; Baede,

351 A. P. M. R.; Guicherit, J. G.; Williams-Jacobse, F. M., Eds. Millpress Science Publishers: Maastricht,

352 Netherlands, 2002; pp 185-190.

353 (11) Reay, D. S.; Edwards, A. C.; Smith, K. A. Importance of indirect nitrous oxide emissions at the

354 field, farm and catchment scale. Agriculture, Ecosystems \& Environment 2009, 133, (3), 163-169. 
(12) Sawamoto, T.; Nakajima, Y.; Kasuya, M.; Tsuruta, H.; Yagi, K. Evaluation of emission factors for indirect $\mathrm{N}_{2} \mathrm{O}$ emission due to nitrogen leaching in agro-ecosystems. Geophysical Research Letters 2005, 32, (3),L03403.

(13) Hiscock, K.; Bateman, A.; Mühlherr, I.; Fukada, T.; Dennis, P. Indirect emissions of nitrous oxide from regional aquifers in the United Kingdom. Environmental Science \& Technology 2003, 37, (16), 3507-3512.

(14) Weymann, D.; Well, R.; Flessa, H.; Heide, C.; Deurer, M.; Meyer, K.; Konrad, C.; Walther, W. Groundwater $\mathrm{N}_{2} \mathrm{O}$ emission factors of nitrate-contaminated aquifers as derived from denitrification progress and $\mathrm{N}_{2} \mathrm{O}$ accumulation. Biogeosciences 2008, 5, (5), 1215-1226.

(15) Höll, B. S.; Jungkunst, H. F.; Fiedler, S.; Stahr, K. Indirect nitrous oxide emission from a nitrogen saturated spruce forest and general accuracy of the IPCC methodology. Atmospheric Environment 2005, 39, (32), 5959-5970.

(16) Hinshaw, S. E.; Dahlgren, R. A. Dissolved nitrous oxide concentrations and fluxes from the eutrophic San Joaquin River, California. Environmental Science \& Technology 2013, 47, (3), 13131322.

(17) Minamikawa, K.; Eguchi, S.; Nishimura, S.; Ihara, H.; Maeda, M.; Yagi, K.; Komada, M. Groundwater-induced emissions of nitrous oxide through the soil surface and from subsurface drainage in an Andosol upland field: A monolith lysimeter study. Soil Science and Plant Nutrition 2013, 59, (1), 87-95.

(18) McGonigle, D.; Burke, S.; Collins, A.; Gartner, R.; Haft, M.; Harris, R.; Haygarth, P.; Hedges, M.; Hiscock, K.; Lovett, A. Developing Demonstration Test Catchments as a platform for transdisciplinary land management research in England and Wales. Environmental Science: Processes \& Impacts 2014, 16, (7), 1618-1628.

(19) Meteorological Office UK climate averages; http://www.metoffice.gov.uk/public/weather/climate/u12gmt1fz.

(20) Lemon, E.; Lemon, D. Nitrous oxide in freshwaters of the Great Lakes Basin. Limnology and Oceanography 1981, 26, (5), 867-879. 
(21) Bowden, W. B.; Bormann, F. Transport and loss of nitrous oxide in soil water after forest clearcutting. Science 1986, 233, (4766), 867-869.

(22) Reay, D.; Smith, K.; Edwards, A. Nitrous Oxide in Agricultural Drainage Waters Following Field Fertilisation. Water, Air and Soil Pollution: Focus 2004, 4, (2-3), 437-451.

(23) Weiss, R.; Price, B. Nitrous oxide solubility in water and seawater. Marine Chemistry 1980, 8 , (4), 347-359.

(24) Sander, R. Compilation of Henry's law constants for inorganic and organic species of potential importance in environmental chemistry. In Report of the Max Planck Institute of Chemistry, Mainz, Germany: 1999.

(25) Clough, T.J.; Buckthought, L. E.; Kelliher, F. M.; Sherlock, R. R. Diurnal fluctations of dissolved nitrous oxide $\left(\mathrm{N}_{2} \mathrm{O}\right)$ concentrations and estimates of $\mathrm{N}_{2} \mathrm{O}$ emissions from a spring-fed river: implications for IPCC methodology. Global Change Biology 2007, 13, 1016-1027.

(26) Ventikeswaran, J. J.; Rosamond, M. S.; Schiff, S. L. Nonlinear response of riverine $\mathrm{N}_{2} \mathrm{O}$ fluxes to oxygen and temperature. Environmental Science \& Technology 2014, 48, 1566-1573.

(27) Nevison, C. Review of the IPCC methodology for estimating nitrous oxide emissions associated with agricultural leaching and runoff. Chemosphere - Global Change Science 2000, 2, (3-4), 493-500. (28) Seitzinger, S. P.; Kroeze, C. Global distribution of nitrous oxide production and N inputs in freshwater and coastal marine ecosystems. Global Biogeochemical Cycles 1998, 12, (1), 93-113. (29) Cardenas, L.; Gooday, R.; Brown, L.; Scholefield, D.; Cuttle, S.; Gilhespy, S.; Matthews, R.; Misselbrook, T.; Wang, J.; Li, C. Towards an improved inventory of $\mathrm{N}_{2} \mathrm{O}$ from agriculture: model evaluation of $\mathrm{N}_{2} \mathrm{O}$ emission factors and $\mathrm{N}$ fraction leached from different sources in UK agriculture. Atmospheric Environment 2013, 79, 340-348.

(30) Well, R.; Butterbach-Bahl, K. Indirect emissions of nitrous oxide from nitrogen deposition and leaching of agricultural nitrogen. In Nitrous Oxide and Climate Change, K, S., Ed. Earthscan Publications Ltd: Sterling, UK, 2010; p 162.

(31) Reay, D. S.; Smith, K. A.; Edwards, A. C.; Hiscock, K. M.; Dong, L. F.; Nedwell, D. B. Indirect nitrous oxide emissions: revised emission factors. Environmental Sciences 2005, 2, (2-3), 153-158. 
409 (32) Syakila, A.; Kroeze, C. The global nitrous oxide budget revisited. Greenhouse Gas Measurement 410 and Management 2011, 1, (1), 17-26.

411 (33) National Atmospheric Emissions Inventory Website; http://naei.defra.gov.uk/.

412

413

414

415

416

417

418

419

420

421

422

423

424

425

426

427 
430 Table 1: Summary of the field drain and stream water $\mathrm{NO}_{3}$ and $\mathrm{N}_{2} \mathrm{O}$ concentration data differentiated

431 by season for the period April 2013 to April 2015. Different superscript letters reflect significant 432 differences $(t$-test $p<0.05)$ between seasons of the same sample type. Different subscript letters 433 reflect significant differences between different sample types.

\begin{tabular}{|c|c|c|c|c|}
\hline Sample type & Season & $\begin{array}{r}\text { Mean } \mathrm{NO}_{3} \\
\left(\mathrm{mg} \mathrm{L}^{-1}\right) \pm \mathrm{SD}\end{array}$ & $\begin{array}{r}\text { Mean } N_{2} O \\
\left(\mu \mathrm{g} \mathrm{L}^{-1}\right) \pm \mathrm{SD}\end{array}$ & $\begin{array}{r}\text { Mean } \mathrm{N}_{2} \mathrm{O}-\mathrm{N} / \mathrm{NO}_{3}^{-}-\mathrm{N} \\
\text { Ratio } \pm \text { SD }\end{array}$ \\
\hline Field drain & $\begin{array}{l}\text { Overall }(n=621) \\
\text { Spring }(n=187) \\
\text { Summer }(n=62) \\
\text { Autumn }(n=153) \\
\text { Winter }(n=219)\end{array}$ & $\begin{array}{l}6.08 \pm 4.78^{a} \\
5.98 \pm 4.64^{\mathrm{a}} \\
4.17 \pm 4.30^{\mathrm{b}} \\
6.42 \pm 5.16^{\mathrm{a}} \\
6.47 \pm 4.65^{\mathrm{a}}\end{array}$ & $\begin{array}{l}4.49 \pm 4.46^{a} \\
4.95 \pm 4.86^{\mathrm{a}} \\
3.20 \pm 4.69^{\mathrm{b}} \\
4.12 \pm 4.73^{\mathrm{a}} \\
4.71 \pm 3.72^{\mathrm{a}}\end{array}$ & $\begin{array}{l}0.00120 \pm 0.00134 a \\
0.00123 \pm 0.00143^{\mathrm{a}} \\
0.00135 \pm 0.00158^{\mathrm{a}} \\
0.00113 \pm 0.00137^{\mathrm{a}} \\
0.00117 \pm 0.00116^{\mathrm{a}}\end{array}$ \\
\hline Stream & $\begin{array}{l}\text { Overall }(n=308) \\
\text { Spring }(n=80) \\
\text { Summer }(n=64) \\
\text { Autumn }(n=92) \\
\text { Winter }(n=72)\end{array}$ & $\begin{array}{l}6.70 \pm 3.20^{b} \\
6.61 \pm 1.92^{\mathrm{a}} \\
4.49 \pm 2.79^{\mathrm{b}} \\
7.05 \pm 4.29^{\mathrm{a}} \\
8.30 \pm 1.55^{\mathrm{c}}\end{array}$ & $\begin{array}{l}1.43 \pm 0.84^{\mathrm{b}} \\
1.30 \pm 0.47^{\mathrm{a}} \\
1.02 \pm 0.51^{\mathrm{b}} \\
1.82 \pm 1.24^{\mathrm{c}} \\
1.42 \pm 0.47^{\mathrm{a}}\end{array}$ & $\begin{array}{l}0.00029 \pm 0.00030_{b} \\
0.00021 \pm 0.00008^{a} \\
0.00039 \pm 0.00038^{b} \\
0.00039 \pm 0.00041^{b} \\
0.00018 \pm 0.00007^{c}\end{array}$ \\
\hline
\end{tabular}

434

Table 2: Emission factors $\mathrm{EF}_{5 \mathrm{~g}}$ and $\mathrm{EF}_{5 \mathrm{r}}$ calculated for field drains and stream water using two different methods, the default IPCC (2006) emission factors $\left(\mathrm{EF}_{5}\right)$, and the proposed $\mathrm{EF}_{5 \mathrm{~g}}, \mathrm{EF}_{5 \mathrm{r}}$ from this study. Values presented as the mean \pm 1 standard deviation.

\begin{tabular}{llrr}
\hline Parameter & Units/methodology & $\begin{array}{r}\text { Field drains } \\
\text { (All) }\end{array}$ & $\begin{array}{r}\text { Stream water } \\
\text { (Site A) }\end{array}$ \\
\hline Total area & ha & 21.09 & 0.33 \\
Indirect $\mathrm{N}_{2} \mathrm{O}$ emissions & $\mathrm{kg} \mathrm{N}_{2} \mathrm{O}-\mathrm{N} \mathrm{ha}^{-1} \mathrm{a}^{-1}$ & $0.05 \pm 0.10$ & $5.75 \pm 6.42$ \\
Mean total indirect $\mathrm{N}_{2} \mathrm{O}$ emissions & $\mathrm{kg} \mathrm{N}_{2} \mathrm{O}-\mathrm{N} \mathrm{a}^{-1}$ & $1.04 \pm 2.13$ & $1.90 \pm 2.12$ \\
Total N input & $\mathrm{kg} \mathrm{N} \mathrm{a}^{-1}$ & 2,870 & 64,545 \\
$\mathrm{Frac}_{\mathrm{LEACH}}$ & $\%$ & $34 \pm 29$ & $25 \pm 27$ \\
$\mathrm{EF}_{5 \mathrm{~g}}, \mathrm{EF}_{5 \mathrm{r}}$ & $\mathrm{IPCC}^{6}$ method & $0.0011 \pm 0.0022$ & $0.0001 \pm 0.0001$ \\
$\mathrm{EF}_{5 \mathrm{~g}}, \mathrm{EF}_{5 \mathrm{r}}$ & $\mathrm{N}_{2} \mathrm{O}-\mathrm{N} / \mathrm{NO}_{3}^{-}-\mathrm{N}$ method & $0.0012 \pm 0.0013$ & $0.0003 \pm 0.0003$ \\
$\mathrm{EF}_{5 \mathrm{~g}}, \mathrm{EF}_{5 \mathrm{r}}$ & $\mathrm{IPCC}(2006)$ default & 0.0025 & 0.0025 \\
$\mathrm{Proposed}_{\mathrm{EF}}, \mathrm{EF}_{5 \mathrm{r}}$ & This study & 0.0012 & 0.0002
\end{tabular}

439 
Table 3: Summary of current and previous IPCC (2006) default emission factors for indirect N

442 leaching from agriculture, calculated emission factors from this study and implications for indirect

$443 \quad \mathrm{~N}_{2} \mathrm{O}$ emission estimates from the UK and globally

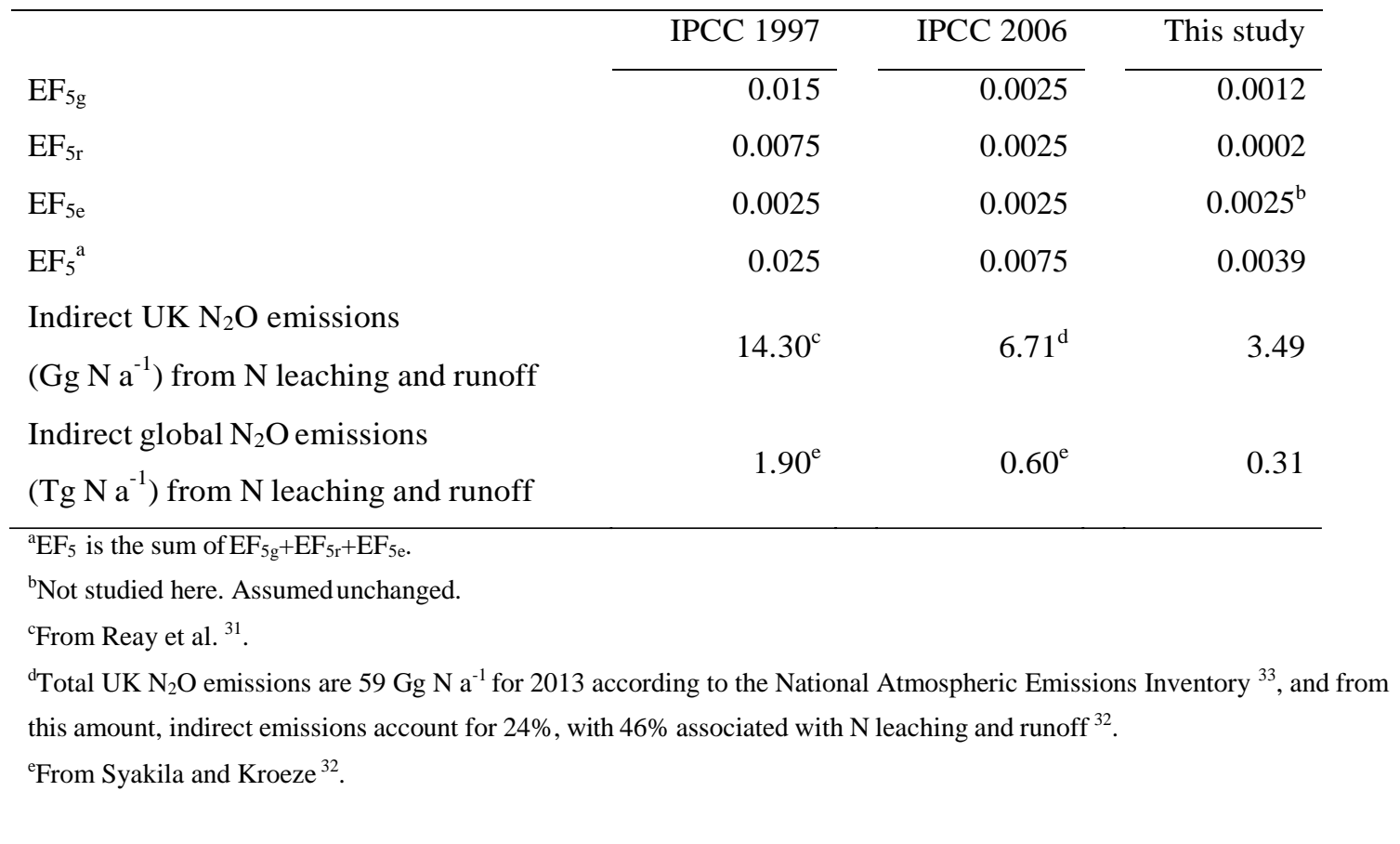

451

452

453

454

455

456

457

458

459 


\section{Figure Captions}

461 Figure 1: Relationship between $\mathrm{N}_{2} \mathrm{O}-\mathrm{N}$ and $\mathrm{NO}_{3}-\mathrm{N}$ in field drain $(n=621)$ and stream water $(n=308)$

462 samples collected during April 2013-April 2015. 90\% of drain samples and 100\% of stream water 463 samples had lower $\mathrm{N}_{2} \mathrm{O}-\mathrm{N} / \mathrm{NO}_{3}^{-}-\mathrm{N}$ ratios than the IPCC (2006) default value of 0.0025.

464

465

466

Figure 2 Temporal variability in the mean $\mathrm{N}_{2} \mathrm{O}-\mathrm{N} / \mathrm{NO}_{3}-\mathrm{N}$ ratio for field drain and stream water samples collected during April 2013-April 2015. Error bars represent one standard error.

467

Figure 3: Input of nitrogen fertiliser $\left(\mathrm{kg} \mathrm{N} \mathrm{ha}^{-1}\right)$ across mini-catchment $\mathrm{A}$ for the (a) 2012-2013 and (b) 2013-2014 farming years.

470 


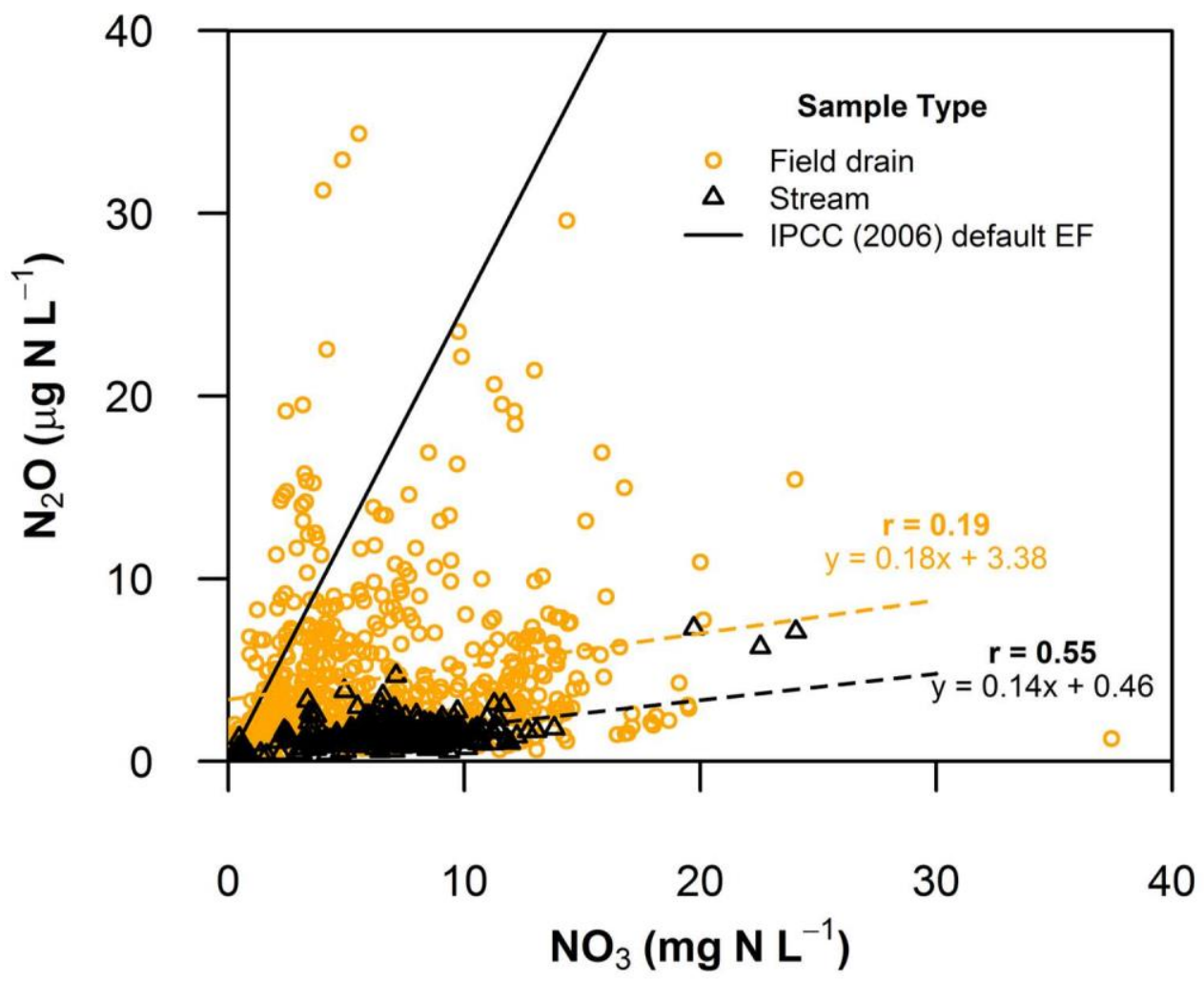

Figure 1: Relationship between N2O-N and NO3-N in field drain $(n=621)$ and stream water $(n=308)$ samples collected during April 2013-April 2015. $90 \%$ of drain samples and $100 \%$ of stream water samples had lower N2O-N/NO3-N ratios than the IPCC (2006) default value of 0.0025 .

$69 \times 57 \mathrm{~mm}(600 \times 600 \mathrm{DPI})$ 


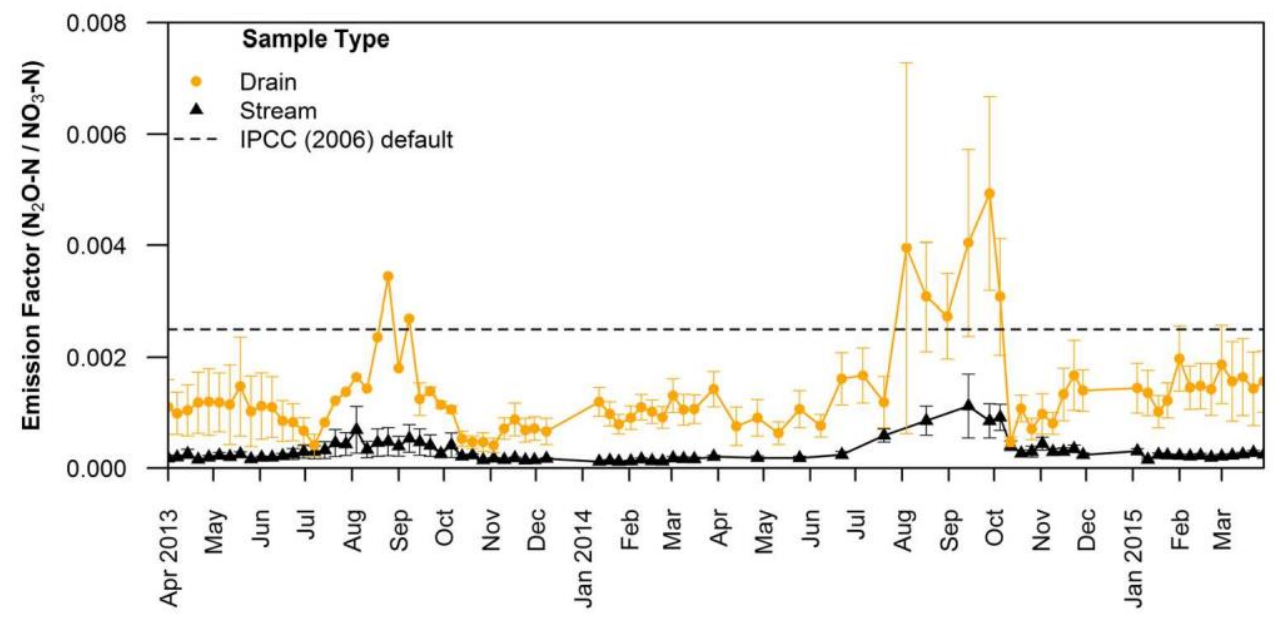

Figure 2 Temporal variability in the mean N2O-N/NO3-N ratio for field drain and stream water samples collected during April 2013-April 2015. Error bars represent one standard error.

$79 \times 39 \mathrm{~mm}(600 \times 600 \mathrm{DPI})$ 

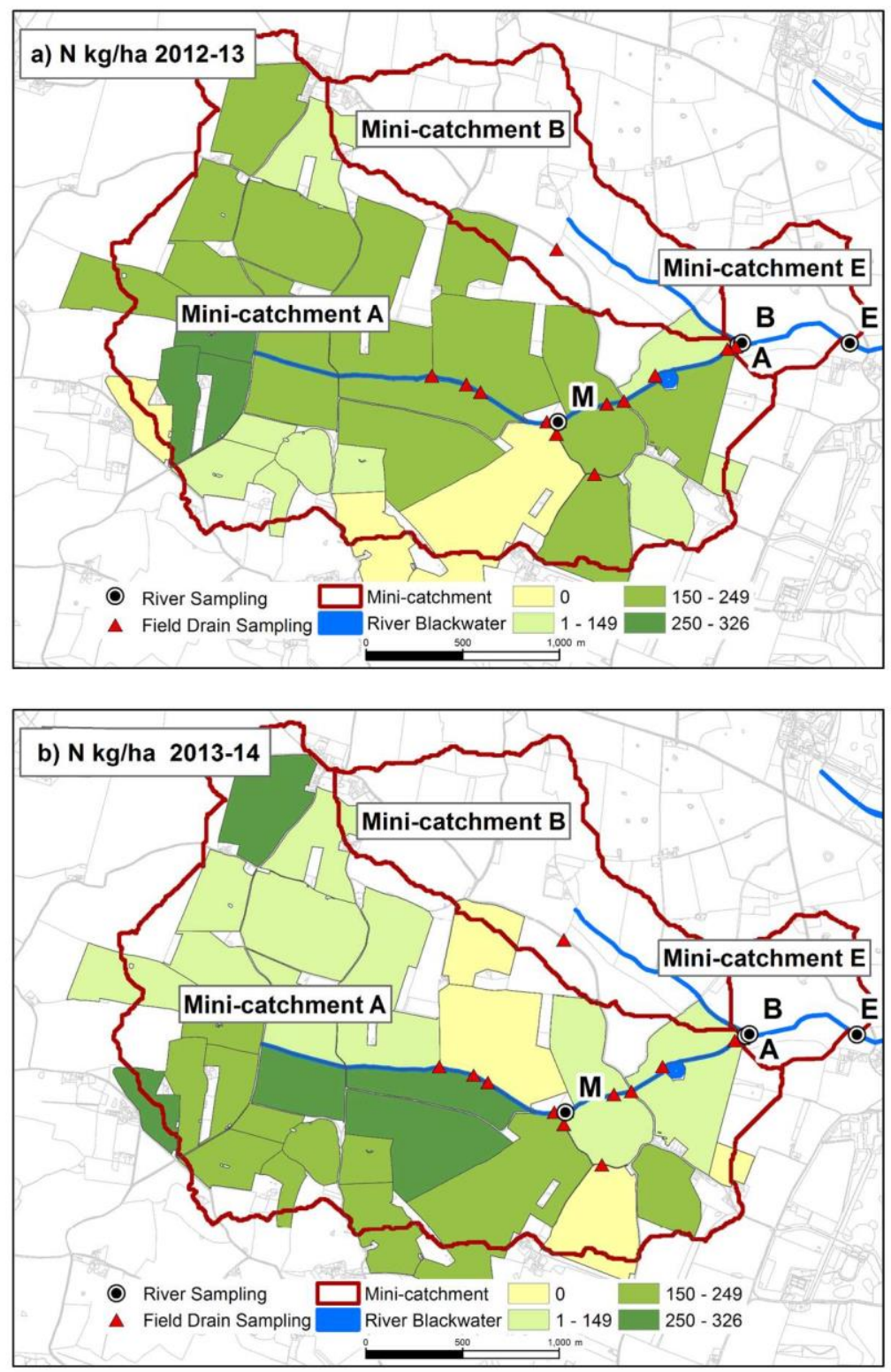

Figure 3: Input of nitrogen fertiliser (kg N ha-1) across mini-catchment $A$ for the (a) 2012-2013 and (b) 2013-2014 farming years.

$130 \times 200 \mathrm{~mm}(300 \times 300 \mathrm{DPI})$ 